\title{
'Be fruitful and multiply': Examining Genesis 1:28 as a basis for the adoption of polygamy as a solution to childlessness amongst Nigerian Christians
}

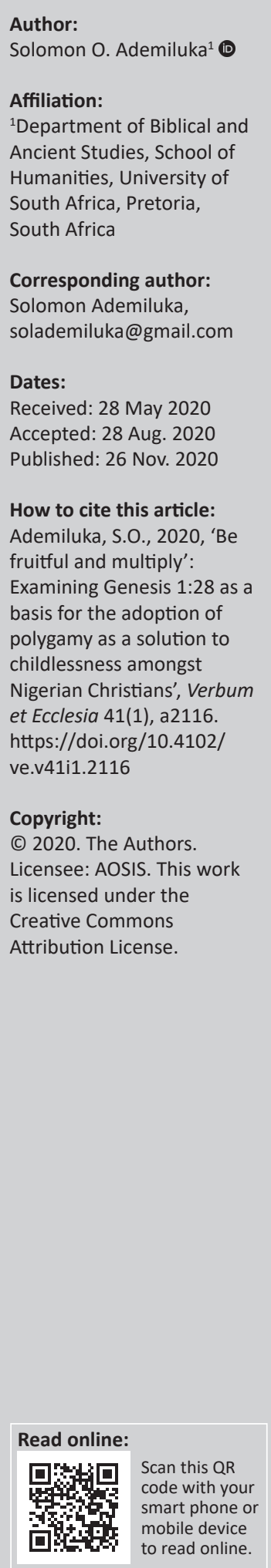

In spite of Christianity and western civilisation, polygamy remains a major issue in Christian marriage in Africa. In Nigeria, most of the mainline churches officially adopt monogamy, whilst many of the African Initiated Churches (AICs) practise polygamy. Because Africans consider procreation as the primary purpose of marriage, some childless Nigerian Christians engage in polygamy in order to have children. But apart from the factor of traditional passion for children, some engage in polygamy to have children because they take the phrase 'Be fruitful and multiply' in Genesis 1:28 as a divine command to everyone to produce children. Therefore, this article examines the text with a view to ascertain whether it is appropriate to exploit the passage as a basis for the adoption of polygamy as a solution to infertility. The target population is those Nigerian Christian men and women who engage in this practice. The article employs descriptive and exegetical methods. It found that, although couched as an imperative, the phrase 'Be fruitful and multiply', rather than being a command to procreate, should be simply understood as a saying that God blessed the humankind with offspring, just as he did the fish that are not expected to obey or disobey (Gn 1:22). It therefore does not provide a basis for adoption of polygamy as a solution to infertility. The article recommends that apart from assisting childless Nigerian Christians to realise their dream of childbearing, the church should make them understand the biblical position that every individual and couple need not have children.

Intradisciplinary and/or interdisciplinary implications: This research involves the disciplines of the Old Testament and Christian Ethics. It examines Genesis 1:28 with regard to the adoption of polygamy as a solution to infertility amongst Nigerian Christians. The article postulates that the passage is not a command for procreation but is simply a saying that God blessed the humankind with offspring; hence, it does not provide a basis for the adoption of polygamy to solve the problem of infertility.

Keywords: 'Be fruitful and multiply'; childlessness; the church; polygamy; Nigerian Christians.

\section{Introduction}

Polygamy ${ }^{1}$ has been at 'the heart of the whole marriage debate within the Church in Africa' since the advent of Christianity in the continent (Falaye 2016:21). Although Christianity and western civilisation have had a diminishing effect on it, polygamy still remains a significant and widespread phenomenon in Africa (Mwambene 2017:7; Okorie 1995:1); hence, 'engagement on this topic is still very important and relevant to the contemporary church and its people' (Baloyi 2013:168). In Nigeria, the officially acceptable form of marriage by most of the mainline churches, as against the African Initiated Churches (AICs), is monogamy. This is not to deny the fact that some of the AICs and neo-Pentecostal denominations also preach the doctrine of 'one man one wife', but many of the AICs practise polygamy. In fact, disagreement over this form of marriage was one of the factors that caused the separation of the AICs from the mission churches ab initio. This doctrine does not give room for any exception; it is one man one wife 'till death do us part'. Usually, most members adhere to this injunction especially if the marriage goes on well. But in Africa the primary purpose of marriage is procreation; therefore, if the African marriage does not go on well, it does not produce children. This is why in Nigeria many members of the anti-polygamy churches whose wives do not bear children engage in polygamy (Egboh 1972:431-444; Ekpendu 2015:81-96). In some cases, the first wife is divorced; sometimes she is retained. Usually, the second marriage is not publicised but if the church finds out, such a member is made to face 1.In this article, the term 'polygamy' is employed in the popular sense of the state of marriage in which there is one husband and two or
more wives, which should strictly be 'polygyny' as against 'polyandry' which refers to a state of one woman marrying two or more husbands (Mbiti 1969:142). 
certain sanctions such as suspension from official positions and certain sacraments. Nonetheless, apart from the traditional perception that every individual must have children, studies on the infertility narrative in Nigeria indicate that some childless Christians find the phrase 'Be fruitful and multiply' in Genesis 1:28 as a divine command to procreate (Okonofua et al. 1977:211; Omeike 2017:19), and thus a reason for engaging in polygamy (Egboh 1972:436; Uchem 2016:1). Therefore, this article examines the text against this type of interpretation, that is, whether it is appropriate to exploit Genesis 1:28 as a basis for the adoption of polygamy as a solution to infertility. It is acknowledged that the Old Testament (OT) in its entirety presents a culture in which polygamy was practised largely unchallenged, especially by the patriarchs and kings. But the childless Nigerian Christians who adopt polygamy as a solution rely more on the Genesis text for scriptural support than on these instances, apparently in view of the imperative tone of the former. Hence, with regard to the biblical aspect, the scope of this study is limited to the Genesis passage. It is also important to clarify that the article is not purposed as a critique of polygamy or to find a solution to it, but simply to determine whether Genesis 1:28 can be used as a basis for practising polygamy as some Nigerian Christians do.

The target population is not easily determinable in that polygamy must necessarily involve the two sexes, a man and at least two women. Nevertheless, oftentimes when polygamy is discussed in the African context, the focus is on the man who marries multiple women, with little attention to the role of women in polygamous relationships. In the traditional setting, the main reason could not be far from the fact that a woman was married out by her parents (precisely by the father) to whomever they wished, the bride having little or no say in the decision. Today, this traditional pattern has transformed to the more 'individualistic pattern based on love and self-selection, especially for educated and urban women' (Ntoimo 2012:1; Ojua, Lukpata \& Atama 2014:44). But even then, a woman still has to wait for a man to ask her hands in marriage, as the 'culture prohibits a woman from making the first move' (Agazue 2016:7). Hence, in the context of a childless marriage in which polygamy is to be employed as a solution, the initiator of polygamy is the man. Nonetheless, the role of the second woman is equally crucial because a polygamous relationship does not exist without it. Therefore, whatever might be the factors informing her involvement, the second woman cannot be absolved in the discourse on polygamy. The target group of this article, then, is Nigerian Christian men and women who engage in polygamy as a solution to childlessness, particularly those who claim to find scriptural support in Genesis 1:28. The work employs the descriptive approach for the examination of polygamy and the church in Africa as well as adoption of polygamy by some Nigerian Christians in dealing with the problem of infertility. It applies the exegetical method for the study of Genesis 1:28. The article begins with a discussion of the issue of polygamy and the church in Africa, from which it proceeds to the examination of adoption of polygamy as a solution to childlessness. Finally, the article attempts an exegesis of Genesis 1:28 with regard to procreation.

\section{Polygamy and the church in Africa}

According to Stent (2019:n.p.), 'by the mid-nineteenth century great missionary outreach to Africa there was almost total consensus amongst Western missionaries that polygamy had no place among Christians'. All the missionary churches 'have always maintained, and still maintain, that acceptance of polygamy would be fundamentally inconsistent with the teaching of Christianity' (Muthengi 1995:57). In their effort to enforce monogamy, the missions differed considerably from one another in the treatment of polygamists. 'Some refused baptism to polygamists while others baptised the wives and children but not the husbands' (Barrett 1968, cited in Muthengi 1995:57). In some places, the missionaries refused to accept polygamists and their families into the church at all. Sometimes, upon conversion to Christianity, polygamous 'husbands were required to choose one customary wife with whom to contract a Christian marriage and abandon the rest, leading to "the discarded wife syndrome" on the continent' (Mwambene 2017:6). In the rest of this section, the article illustrates Christian attitudes to polygamy in Africa with the teaching and practices in the Roman Catholic Church, the Anglican Communion, the Baptist Convention and the AICs.

The official teaching of the Roman Catholic Church on polygamy is based on the resolutions of the Council of Trent of 1563, which summarise that,

[I]f anyone says that it is lawful for Christians to have several wives at the same time, and that it is not forbidden by any divine Law (Mt 19:4f.), let him be anathema. (Gitari 1984:6)

Based on these resolutions, the modern position of the church on polygamy remains, inter alia, that

$[P]$ olygamy is firmly rejected. If a man wishes to be baptised, he must put away all his wives except one. The additional wives of an unbaptised man cannot be baptised. (Gitari 1984:6)

The authorities of the church have consistently maintained this position as its authentic teaching on polygamy. Pope John Paul II in his 1980 visit to Zaire and other parts of Africa reiterated that this Roman Catholic view on polygamy 'has prevailed throughout the centuries' (Muthengi 1995:67). For the Pope, polygamy is as sinful as divorce and abortion (Hillman 1982:166). He explained that (Hillman 1982, cited in Muthengi 1995):

$[P]$ olygamy radically contradicts the covenant of married life ('two in one flesh'), so it negates God's plan which was revealed from the beginning, because it is contrary to the equal personal dignity of men and women who in matrimony give themselves love that is total and therefore unique and exclusive. (p. 67)

The official position of the Anglican Communion is aptly represented in the words of Henry Venn, the chief 
secretary of the Church Missionary Society (CMS) from 1841 to 1872 , when in 1856 he stated in a memorandum that (Gitari 1984):

[T] he state of polygamy is unlawful within the Church of Christ even though commenced in ignorance because it is not only contrary to the Divine institution of marriage, but also Christ pronounced it as adultery and Paul said that, 'Let every man take his own wife, and let every woman have her own husband' [1 Cor 7:2]. (p. 3; Hastings 1973:12)

The Anglican attitude to polygamy is represented generally in the treatment of the members of polygamous families by the middle of the 19th century. For instance, the CMS missionaries in Western Nigeria are said to have resolved that the wives of a polygamist who were true converts might be baptised 'since they are usually the involuntary victims of the custom [but] no man could be admitted who retained more than one wife' (Gitari 1984, cited in Muthengi 1995:72). The 1888 Lambeth Conference formerly passed the resolutions of the church on polygamy, which were confirmed in 1908 and 1920 and 'have remained normative within the Anglican Communion ever since' (Gitari 1984:4). The resolutions state that (Gitari 1984):

[I]t is the opinion of this Conference that persons living in polygamy be not admitted to baptism, but that they be accepted as candidates and kept under Christian instruction until such time as they shall be in a position to accept the law of Christ. The wives of polygamists may, in the opinion of this Conference, be admitted in some cases to baptism, but it must be left to the local authorities of the Church to decide under what circumstances they may be baptised. (pp. 3-4)

Prior to 1920, 'the Baptist Mission [in Nigeria] was considered an exception to the rule' in denying membership to polygamists (Webster 1964, cited in Ejenobo 2010:55). In the southwestern Abeokuta town, S.G. Pinnock was the missionary in charge and was greatly loved by the people because he granted church membership to polygamists, amongst other reasons. However, in 1921, he was compulsorily relieved of his post and replaced by B.L. Lockett who had complained that the Baptist churches in Abeokuta were thoroughly saturated with polygamist members' (Webster 1964, cited in Ejenobo 2010:55). On assuming office, Lockett is said to have excommunicated many polygamists. But it appears that this stance had been relaxed by 1992 on account of the church's 'program of mass evangelisation of the un-reached groups in the country [when it] came to terms with the fact that polygamists had to be baptized' (Ejenobo 2010:56). This leniency, however, did not last long as it became clear later that polygamists were being denied (Handan 2003):

[W]ater baptism, participation in the Lord's Supper and acceptance into the full membership of a local Church. Polygamists are referred to as 'friends', implying that such persons are free to attend Church regularly but without membership privileges and they cannot be elected into a place of leadership. (p. 38)
This position is clearly stated in the constitution of the Baptist Convention of 2000 (cited in Handan 2003) that:

[T] he Convention recognises monogamy as the ideal state of family life according to the New Testament. The convention places on record its adherence thereto. No known polygamist shall be allowed membership in the Churches, to hold any office in the Church, to serve as lay preacher or participate in the ordinances of Baptism and the Lord's Supper. (p. 38)

It must be mentioned, however, that the missionaries were not all unanimous in the rejection of polygamy. Karl Rahner was a Roman Catholic scholar and was favourably disposed towards polygamy, arguing that the African peoples, for example, the Maasai of Kenya and Tanzania, should not be expected to produce the morality of western Christianity. 'Rather, they were to live as Maasai Christians, with all the rights of baptism' (Muthengi 1995:68). Bernard Haring even canvassed for polygamy amongst Africans in the form of levirate and in cases where the first wife is barren (Hillman 1982, cited in Muthengi 1995:68). John Colenso, the first Anglican Bishop of Natal Province in South Africa, appointed in 1853, was the most vehement in challenging the refusal of the Anglican Church to admit polygamists to baptism. In 1862, Colenso wrote a letter to the Archbishop of Canterbury in which he declared as unscriptural and unwarranted

$[T]$ he common practice of requiring a man, who may have more than one wife at the time of his conversion, to put away all but one before he can be received to Christian baptism. (Gitari 1984:4; Muthengi 1995:71)

Colenso was largely ignored but his criticisms seem to have had effect, later on, on the Communion's Lambeth conference in 1988 which resolved that (King 2016):

$[A]$ polygamist who ... wishes to join the Anglican Church may be baptized and confirmed with his believing wives and children on the condition ... the polygamist shall promise not to marry again as long as any of his wives at the time of his conversion are alive and that such a polygamist shall not be compelled to put away any of his wives, on account of the social deprivation they would suffer. (n.p.; Anglican Consultative Council 2019:n.p.)

This position seems not to be enforced, though, because, as seen below, the Communion remains opposed to the practice of polygamy.

Africans' reaction to the mission churches' attitude to polygamy was a major factor underlying the emergence of AICs at the turn of the 20th century (Barrett 1968; Hillman 1975, both cited in Muthengi 1995:74). It all started when certain individuals and groups could no longer adhere to the standard regulations of their mother denominations on the issue of polygamy, amongst others, and found it more convenient to separate and start their own churches (Onah 1996, cited in Ademiluka 2007:3). In Nigeria, for instance, there occurred a great schism amongst the Anglican Churches in Lagos and Abeokuta in the southwestern region, as many polygamists withdrew their financial contributions, accusing 'the clergy of insincerity in 
supporting monogamy, a form of marriage considered foreign to them' (Webster 1964, cited in Handan 2003:25). A spectacular case was that of Jacob Kehinde Coker, 'a leading Anglican layman [who] believed that the Anglican Church's dogmatic principle of monogamy prevented the "heathen" from entering it' (Hastings 1973, cited in Muthengi 1995:72). In 1901, Coker led a secession from the Anglican Church in Lagos, thereby becoming one of the popular founders of the African Church of Nigeria and a leading figure in the AICs. During the crisis which led to the secession, Coker declared to the Assistant Bishop of the Anglican Church,

I was born and bred by a polygamist, I lived amongst polygamists, I am a polygamist and know all about polygamy and I shall stand for polygamy until I die. (Hastings 1973, cited in Muthengi 1995:72)

In these words, one can see a clear foundation for the attitude of the AICs towards polygamy, the foundation which was clearly built upon by many other leading figures. Barrett (1968, cited in Muthengi 1995) states:

[I]saiah Shembe, Messiah of the Nazarite Baptist Church in South Africa, had four wives; Josiah Oshitelu, founder of the Church of the Lord (Aladura) [in southwestern Nigeria] had seven wives; Johane Maranke, founder of the African Apostolic Church in Zambia and Zimbabwe had sixteen wives. (p. 58)

Hence, it is no surprise that many of the AICs have endorsed polygamy as 'part of their conscious indigenisation of Christianity in Africa' (Hillman 1975, cited in Muthengi 1995:58). Because of their leniency towards polygamy, amongst other factors, the AICs grew rapidly drawing their membership principally from the mission churches, particularly those members who felt ill-treated by the latter (Baloyi 2013:175). Concluding on the attitude of the church in Africa towards polygamy, Muthengi (1995) states:

$[O]$ ne thing clearly stands out, namely, that all the major mission and church organisations ... have condemned polygamy and endorsed monogamy [while] ... there has been a high degree of flexibility among the African Independent Churches, many of whom have accepted polygamy as part of their expression of authentic African Christianity. (p.75)

Nonetheless, as Falaye (2016:21) rightly affirms, 'the debate, controversy, polemic or argument on polygamy [which have been] ... raging for quite some years in the history of the church' in Africa are yet to be abated because the practice is still very much on (Mwambene 2017:6). In Nigeria, the practice of polygamy amongst Christians is yet unabated, and remains a concern to the church. Hence, Archbishop Peter Akinola had 'to write to all Anglican Communions in the country to desist from such practice, which he described as unscriptural [and] could make a mockery of the church' (BBC 2008:n.p.). Similarly, Cardinal John Onaiyekan of the Catholic Diocese of Abuja declared against polygamy that 'the Catholic Church is particularly firm and consistent, giving no room whatsoever for doubts and exceptions' (Allen 2014:n.p.). However, in accordance with the aim of this article, the next section focuses on the adoption of polygamy as a response to childlessness amongst Nigerian Christians.

\section{Adoption of polygamy as a solution to childlessness amongst Nigerian Christians}

In confirmation of Archbishop Akinola's concern referred in the previous section, many have made reference to the prevalence of polygamy amongst Nigerian Christians. In the same story in which the Archbishop's letter is alluded to (BBC 2008), it is stated that 'as much as $10 \%$ of some congregations in [northern Nigeria] can be in polygamous marriages'. As stated in the constitution of the Baptist Convention cited above, Christian polygamists are still being sanctioned in some mainline churches. Whilst the Baptist Church will not grant polygamists full membership of the church, some other denominations do not officially recognise extra wives and their children, and they will not be baptised by the church. For instance, in the Anglican Communion, 'polygamous converts are prevented from taking leadership positions in the church until they accept monogamy' (BBC 2008:n.p.). Similarly, in the Evangelical Church Winning All (ECWA), polygamous members are not eligible for the position of elders. ${ }^{2}$ Ahmed (1985:20) observes that in Nigeria and Africa at large, 'the change from polygyny to monogamy could not be carried out smoothly [because] ... polygyny developed to fulfill certain social, economic, and sexual conditions'. The strongest of such conditions is the fact that in African perception, procreation is the primary purpose of marriage. Unlike in the western society where marriage is person-oriented, 'that is, the concept of marriage as companionship', in the traditional African setting, marriage is fertility-oriented (Emenusiobi 2013:n.p.; Abasili 2011:567). Mbiti (1969) explains that in Africa:

[T] he supreme purpose of marriage is to bear children to build a family, to extend life and to hand down the living torch of existence ... [Hence] if there is not yet a child in the marriage people do not consider it to be a marriage [and] there is no guarantee that the marriage will endure. (pp. 132-133; Egede 2015:65; Baloyi 2017:3)

As another writer puts it, in Africa 'the sense of children ... as a value to be desired - is so strong' that it overrides other purposes of marriage such as compatibility (Marriage \& Family 1988:n.p., emphasis in original). In fact, in the traditional African setting, 'the indissolubility of marriage is conditioned to its fruitfulness. Practically speaking, the birth of a child marked the "consummation" of the marriage' (Marriage \& Family 1988:n.p.). Having children is so significant that it is unthinkable for one to die without having children; it means to 'be completely cut off from the human society, to become an outcast and to lose all links with mankind' (Mbiti 1969:133). For this reason, 2.The present author is a member of ECWA. 
amongst the Igbo of southeastern Nigeria, for instance (Abasili 2011):

$[F]$ or a man ... to die childless or without a male child is a calamity; it is tantamount to a descent into oblivion, to be forgotten by both the living and the dead ... He is not admitted into the status of an Igbo ancestor after his death, which requires one to have children. (p. 567)

It is important to note that the African man's desperation is indeed for male children, since as mentioned above, every man wants a heir after his death. That is why even if the wife has children, but bears 'only daughters, it follows almost without exception that her husband will add another wife' (Mbiti 1969:143). Igbelina-Igbokwe (2013) states that oftentimes men:

[T]ake second wives because of their first wife's inability to bear an heir. Therefore a woman with no sons ... lives in constant fear of losing her marriage ... to another who may be brought in to correct her 'inadequacies'. (n.p.)

Another explanation for this attitude is that whereas a male child is looked upon as the sustainer of the lineage, girls are 'perceived as expendable commodities who will eventually be married out to other families to procreate and ensure the survival of the spouses' lineage by bearing sons' (IgbelinaIgbokwe 2013). Apart from the danger of losing her marriage, the barren woman suffers the stigmatisation of childlessness more than her husband. In the description of Mbiti (1969, cited in Egede 2015), the childless wife is the:

$[D]$ ead end of human life, not only for genealogical level, but also for herself ... [She] bears a scar which nothing can erase. She will suffer for this; her own relations will suffer for it. It is an irreparable humiliation for which there is no source of comfort in traditional life. (p. 66)

In some places, childless women are objects of public ridicule; they are 'despised, scorned, pitied and shunned' (Egede2015:56).

Whilst the desperation for children is 'the primary determinant of polygamy' (Uchem 2016:15), it should be mentioned that there are other reasons why the African man marries several wives, but these would apply more to the past than to the modern time. In those days, children were a form of wealth because many children would provide more hands to work in the field to produce food and cash crops or livestock for sale. Thus, in a way 'a man's wealth was measured by the number of his wives as well as the number of his children' (Olasore 2016:9). Polygamy, therefore, 'enhanced the economic and social status of both women and men [for which reason sometimes women] ... encouraged their husbands to take more wives' (Uchem 2016:14). However, since a barren woman faces the danger of losing her marriage, it might be that, apart from the burden of manual work, sometimes barren women enter into a mutual arrangement with their husbands to have a second wife for fear of being divorced (Ekpendu 2015:84). Polygamy also served other functions in the traditional African setting (Baloyi 2013:168-173; Mwambene 2017:5). It was a solution to menopause in places where people had the belief that women in menopause might no longer engage in sexual intercourse whereas their husbands would be in need of sex. Similarly, polygamy was a remedy for men in societies where sex was forbidden for pregnant women and nursing mothers. It also provided matrimonial accommodation for widows and their children in places where the relative of a deceased man had the responsibility to marry his late brother's wife or wives in addition to his own, in order to raise children for the deceased (Mbiti 1969:134). Thus, apart from seeking treatment for infertility from indigenous healers, faith-healing and biomedical practitioners (Dimka \& Dein 2013:111; Pearce 1999:71), some Nigerian Christians engage in polygamy as a solution.

Nevertheless, there are indications that the infertile Nigerian Christians' desperation to change their status derives not only from the traditional attitude towards procreation but also from the idea ostensibly derived from the phrase 'Be fruitful and multiply' in Genesis 1:28 that every individual must have children. Scholars attest that this passage has been given this interpretation over the generations. According to Moss and Baden (2015), perhaps because they were given to the 'first two men', Adam and Noah:

[F]or thousands of years, the words ['Be fruitful and multiply'] have been understood as a divine imperative to each and every individual ... to produce offspring ... If one chooses not to bear children, then one could be seen as violating a direct divine command ... If one is unable to bear children, one is considered cursed. (pp. 70, 72)

Ryan (2005) most likely had Genesis 1:28 in mind, amongst other passages, when he stated that:

$[T]$ he interwoven symbolisms of judgment, blessing and mystery [in some bible references] yield a confusing answer to the suffering occasioned by infertility. Infertile women, in particular, are tempted to blame themselves ... for their present inability to conceive or bear a child; some believe that they are being punished by God for their earlier ambivalence about having children. (p. 69)

In Nigeria, a few studies on the infertility narrative have buttressed the fact that some infertile Christians have this understanding of Genesis 1:28, taking it as a divine command to everyone to bear children. For example, Omeike (2017:19) attests to a reaction towards the Genesis text amongst the Igbo of the southeastern region when he states that their natural inclination 'for fertility has been reinforced by biblical and ecclesial emphasis on fruitfulness'. In a study conducted by Okonofua et al. (1997:211) in southwestern Nigeria, some childless persons gave several reasons for wanting to have children, amongst which was 'to obey the command of God to "go forth and multiply"'. This reason is clearly a reference to Genesis 1:28 because the respondents in the study were composed 'largely [of] Christian population' (Okonofua et al. 1997:211). There is also abounding evidence in the infertility narrative that such childless Nigerian Christians who consider themselves to be under the divine command to bear children do engage in polygamy as a solution. For instance, Egboh (1972:436) asserts that some Nigerian Christians 'become polygamous because ... their Christian 
marriage is a failure on account of childlessness or because of the failure [to have] male offspring to succeed them after death'. Similarly, Uchem (2016:1) opines that the desire for children is 'the basic cause of the perpetuation of polygamy even among Christians'. Therefore, the next section examines Genesis 1:28 in relation to procreation to ascertain whether or not it supports adoption of polygamy as a solution to childlessness.

\section{Genesis 1:28 and procreation: An exegesis}

The OT presents a culture in which polygamy was practised largely unchallenged, with instances like those of Abraham (Gn 16), Jacob (Gn 29-30), Elkanah (1 Sm 1), King David who married many wives and kept numerous concubines simultaneously (2 Sm 5:13) and Solomon who is recorded to have accumulated the largest number of women ever known (I Ki 11:1-3). To this end, it is generally accepted amongst scholars that the OT is not opposed to polygamy (Barth 1961, cited in Ejenobo 2010:55; Cocherell 2015, cited in Stent 2019:n.p.; Hillman 1975, cited in Muthengi 1995:61). Nonetheless, the childless Nigerian Christians who adopt polygamy as a solution are not likely to be compelled by these instances but by the belief that they are under a divine command to produce children; hence, the perceived scriptural support for them resides more in Genesis 1:28, as earlier discussed.

Genesis 1:28 belongs to the priestly account of creation in 1:1-2:4a. In 1:26-28, 'the highpoint and goal has been reached toward which all of God's creativity from v. 1 on was directed', that is, the creation of the humankind (Davidson 1988:5). After creating mankind in verse 27, verse 28 states:

[A]nd God blessed them, and God said to them, 'Be fruitful and multiply, and fill the earth and subdue it; and have dominion over the fish of the sea and over the birds of the air and over every living thing that moves upon the earth'. (RSV) (v. 28)

The concern of this article, however, is with the phrase 'Be fruitful and multiply', פּרו in פורו in the qal imperative of the verb פרה , meaning 'to bear fruit'. According to Koehler and Baumgartner (2000), פרה refers specifically to 'the fruit of the vine, or of the fig tree but more importantly to the fruit of the womb, resulting from intercourse between the male and female' (cited in Ahiamadu 2010:99). רבו is also the qal imperative of the root רבה, 'to be many' or 'to be great'. The root 'is a word used mostly in quantitative contexts, but sometimes also in a metaphorical sense', meaning 'to have many children' as in 1 Chronicles 7:4 (Ahiamadu 2010:100). There appears to be no controversy on the translation of the phrase, as many English versions render it as 'Be fruitful and multiply' (e.g. RSV, NRSV, KJV, NJKV and NASB). The NIV translates it as 'Be fruitful and increase in number', which is not in contention with these other versions. According to the

3.The English Bible versions used in this article are abbreviated as follows: Revised Standard Version (RSV); New Revised Standard Version (NRSV); King James Version (KJV); New King James Version (NKJV); New American Standard Bible (NASB); New (KJV); New King James Version (NKJV); New American Sta
International Version (NIV); Today's English Version (TEV). priestly account, 'Be fruitful and multiply' were God's first words to mankind. The same words are repeated to Noah after the Flood (Gn 9:1,7). They appear in similar forms again to Abraham (17:6) and to Jacob (35:11). Davidson (1988:10) opines that it is clear from this phrase that 'one of the primary purposes of sexuality is procreation ... Procreation is shown to be part of the divine design for human sexuality - as a special added blessing'. Moss and Baden (2015) assert that the words have been understood for generations as a divine imperative that every individual must have children, as mentioned earlier. Magnuson (2000:26) states that in Jewish tradition and interpretation, the phrase 'is considered to be a moral imperative, a religious duty that is meant to channel sexual passion for the purpose of the perpetuation of humankind'. Hence, in the Mishna (Moss \& Baden 2015):

$[A]$ man must not abstain from 'be fruitful and multiply' unless he already has children, [the] law [which] was taken up and applied in midrash over the next eight centuries as a staple of rabbinic thought. (p. 71)

In Christian theology, Genesis 1:28 is often interpreted as 'a moral command expressed in terms of a creation mandate' (Magnuson 2000:27). Wenham (1987:33), for instance, indicates that, following Genesis 1:27 ('male and female he created them', RSV), the imperative to 'be fruitful and multiply' in verse 28 is a pointer to procreation as the divine purpose of marriage. Karl Barth (1956-1975, cited in Magnuson 2000:27) interprets Genesis 1:28 in terms of 'the propagation of the race [which was] an unconditional command [until] the advent of Christ'), whilst Peel (1987:328) asserts that 'God's first recorded command to humans was to procreate'. Indeed, with regard to the grammatical construction and the context of Genesis 1, Genesis 1:28 lends itself to a reading as a command (Magnuson 2000:27). According to Magnuson (2000):

$[T]$ he statement is in the form of an imperative and it fits with the pattern of 'command and execution' throughout [the chapter]. [For instance,] God creates the 'expanse' (1:6-8), and commands the celestial bodies to fill it (1:14-18); he creates the sky (1:6-8) and the seas (1:9-10), and commands the birds and the sea creatures to fill them (1:20) ... The will of the Creator is made clear through His command, and His creatures are left to carry out His command. It is not difficult, therefore, to understand why procreation is taken as a moral command, a creation mandate or religious duty. (p. 27)

Nonetheless, as Moss and Baden (2015) rightly observe, ‘Be fruitful and multiply' is better read as a blessing rather than a command. In the first place, neither Noah nor Jacob had children again after they received the words. 'If God's words are understood as a command, then we would have to conclude that both Noah and Jacob are guilty of disobeying the divine will' (Moss \& Baden 2015:74). It is also important to note that 'the imperative is grouped with others, including filling, ruling and subduing the earth, which are not promoted as moral duties' (Magnuson 2000:28). Moreover, the same words are said to the fish of the seas (Gn 1:22), which are 'obviously not intended to become responsible for their reproduction' (Daube 1977:3). 
Whereas if the text is read as a blessing, the question of obedience or disobedience does not arise; instead, the responsibility resides with God to fulfil his words. As Magnuson (2000) puts it:

[W]hile human beings can demonstrate an openness to procreation, it is God alone who creates life. Since life is a gift from God (Psalm 127:3), understanding procreation as a command may place too much emphasis upon human procurement of God's blessing. (p. 28)

\section{Moss and Baden (2015) further state that:}

There are abundant reasons, therefore, for rejecting the common, if not universal, view that the words 'be fruitful and multiply' should be taken as a divine imperative to procreate, one that can be either obeyed or disobeyed. (p. 74)

Furthermore, the blessing of children in Genesis 1:28 should not be read as applying to individuals or something that is passed down genetically from Adam or Noah (Moss \& Baden 2015:75). For, if it were so understood, there would have been no need to repeat it to Abraham and Jacob. The blessing is best understood in light of its functional parallel in Genesis 12:2: 'And I will make of you a great nation, and I will bless you, and make your name great, so that you will be a blessing' (RSV). In other words, the promise of children was not necessarily for Abraham and Jacob as individuals, but had in mind 'the people who, far in the future, will descend from those who are blessed' (Moss \& Baden 2015:75). Monroe and Monroe (2005:50) put it succinctly as, '[c]hildren are a blessing, but they are not promised to us individually'.

Nevertheless, some have insisted that Genesis 1:28 should be understood in the context of marriage, as 'we cannot think of ... procreation in abstraction from marriage' (Murray 1957, cited in Magnuson 2000:27). As stated earlier, Wenham (1987:33) believes that Genesis 1:28, coming after Genesis 1:27, indicates the divine purpose of marriage. For these interpreters, therefore, this passage has to be studied in the context of Genesis 2:18-24, which many have 'recognized as a narrative on the divine institution of marriage and the beginning of human family' (Jerome 2016:528). In other words, understanding 'Be fruitful and multiply' in the context of marriage strengthens the argument that it is a command to procreate since, according to these scholars, the primary purpose of marriage in Genesis 2 is procreation. However, whilst the argument on marriage and procreation does not fall within the scope of this article, it is necessary to state that many scholars attest to the fact that companionship, rather than childbearing, is the purpose of marriage in Genesis 2 (e.g. Birch et al. 2005:46; Davidson 1988:11, 22; Magnuson 2000:33). Therefore, although couched as an imperative, the phrase 'Be fruitful and multiply' cannot be a command to procreate. It sounds convincing particularly that insofar as the same words are given to the fish that are naturally not expected to obey or disobey (Gn 1:22), the phrase should rather be simply understood as a saying that God blessed the humankind with offspring, just as he did with the fish. In closing, since the Christian life is ruled by the
New Testament (NT), and not by the OT, it is pertinent to mention that this interpretation finds support in the NT, particularly in Paul's teaching on marriage in 1 Corinthians 7 (vv. 1-7), where the apostle expressly states that not everyone must get married which implies not everyone must have children (Moss \& Baden 2015:191).

\section{Conclusion and recommendation}

In Nigeria, as in Africa at large, procreation is considered as the primary purpose of marriage. This is why childlessness is the most unbearable problem for Africans, including Christians. One of the desperate approaches to this problem by some Nigerian Christians is the adoption of polygamy for the purpose of having children. But apart from the traditional perception that one must have children, relying on Genesis 1:28, some Christians also believe that the Bible commands everyone to have children. However, this article found that the phrase 'Be fruitful and multiply' in Genesis 1:28 simply means that God gives children as a blessing to mankind, but not a divine command for every individual to produce children. This finding is in consonance with Paul's teaching in 1 Corinthians 7 that not everyone must get married, which means not everyone must have children. Therefore, Genesis 1:28 does not provide a basis for the adoption of polygamy as a solution to childlessness. Whilst this conclusion adequately fulfils the aim of this study, it is necessary to recommend that apart from assisting childless Nigerian Christians in various ways to realise their dream of childbearing, the church needs to make them understand the biblical perspective on procreation, namely, that everyone need not bear children. Although it will be an assiduous task to make Africans accept any proposition of a child-free life, given their traditional passion for children, it is the truth that the church needs to accept and teach in the discharge of its pastoral duties. To achieve this goal, the church in Nigeria has to develop (Ryan 2005):

$[A]$ theological reconstruction of the place of procreation in a theology of marriage [that] will mitigate the undue emphasis on procreation ... [which] tends to render the childless marriage second class [or deficient]. (pp. 72-73)

The church's theology on marriage should encourage childless couples to imbibe the attitude of self-acceptance by which they can find satisfaction in their marital relationships.

\section{Acknowledgements Competing interests}

The author has declared that no competing interests exist.

\section{Author's contributions}

I declare that I am the sole author of this research article.

\section{Ethical consideration}

This article followed all ethical standards for research without direct contact with human or animal subjects. 


\section{Funding information}

This research received no specific grant from any funding agency in the public, commercial or not-for-profit sectors.

\section{Data availability statement}

Data sharing is not applicable to this article as no new data were created or analysed in this study.

\section{Disclaimer}

The views and opinions expressed in this article are those of the author and do not necessarily reflect the official policy or position of any affiliated agency of the author.

\section{References}

Abasili, A.l., 2011, 'Seeing Tamar through the prism of African woman: A contextual reading of Genesis 38', Old Testament Essays 24(3), 555-573.

Ademiluka, S.O., 2007, Issues at stake in the contemporary Nigerian Church, Nathadex, llorin.

Agazue, C., 2016, "'He told me that my waist and private parts have been ravaged by demons": Sexual exploitation of female church members by "prophets" in Nigeria', Dignity: A Journal on Sexual Exploitation and Violence 1(1), 1-16. https:// doi.org/10.23860/dignity.2016.01.01.10

Ahiamadu, A., 2010, 'A postcolonial critical assessment of the imago dei in Gen 1:26-28 in Nigerian perspective', Scriptura 103(1), 97-106. https://doi. org/10.7833/103-0-591

Ahmed, J., 1985, 'Polygyny and fertility differentials among the Yoruba of western Nigeria', MA thesis, Australian National University, Canberra.

Allen, J.L., 2014, 'Surprise! One of the church's family issues is polygamy', Crux: Taking the Catholic Pulse, viewed 11 July 2019, from https://cruxnow.com/ church/2014/09/11/surprise-one-of-the-churchs-family-issues-is-polygamy/.

Anglican Consultative Council, 2019, 'Resolution 26-Church and polygamy', Anglican Communion, viewed 15 July 2019, from https://www.anglicancommunion.org/ resources/document-library/lambeth-conference/1988/resolution-26-churchand-polygamy?subject=Marriage\&language=English.

Baloyi, M.E., 2013, 'Critical reflections on polygamy in the African Christian context', Missionalia 41(2), 164-181. https://doi.org/10.7832/41-2-12

Baloyi, M.E., 2017, 'Gendered character of barrenness in an African context: An African pastoral study', In Die Skriflig 51(1), 1-10. https://doi.org/10.4102/ids.v51i1.2172

Baptist Convention, 2000, The constitution and byelaws of the Nigerian Baptist convention, Baptist Press, Ibadan.

Barrett, D.B., 1968, Schism and renewal in Africa, Oxford University Press, Nairobi.

BBC, 2008, 'Warning for Christian polygamists', BBC News Africa, viewed 23 December 2018, from http://news.bbc.co.uk/2/hi/africa/7392524.stm.

Birch, B.C., Brueggemann, W., Fretheim, T.E. \& Petersen, D.L., 2005, A theological introduction to the Old Testament, 2nd edn., Abingdon, Nashville, TN.

Cocherell, B.L., 2015, 'Polygamy', Bible Research Org, viewed 05 May 2015, from http://www.bibleresearch.org/articles/alw2.htm.

Daube, D., 1977, The duty of procreation, Edinburgh University Press, Edinburgh.

Davidson, R.M., 1988, 'The theology of sexuality in the beginning: Genesis 1-2', Andrews University Seminary Studies 26(1), 5-21.

Dimka, R.A. \& Dein, S.L., 2013, 'The work of a woman is to give birth to children: Cultural constructions of infertility in Nigeria', African Journal of Reproductive Health/La Revue Africaine de la Santé Reproductive 17(2), 102-117.

Egboh, E.O., 1972, 'Polygamy in Iboland (South-Eastern Nigeria) with special reference to polygamy practice among Christian Ibos', Civilisations 22(3), 431-444.

Egede, H., 2015, 'The social stigmatisation of involuntary childless women in subSaharan Africa: The gender empowerment and justice case for cheaper access to assisted reproductive technologies?', PhD thesis, Cardiff University, Wales.

Ejenobo, D.T., 2010, 'Attitude critique of the Nigerian churches to the practice of polygamy in Nigeria', International Journal of Theology \& Reformed 2(1), 42-67.

Ekpendu, I.C., 2015, 'A biblical response to the practice of polygamy in eastern Nigeria', Asia-Africa Journal of Mission and Ministry 11(1), 81-96. https://doi. org/10.21806/AAMM.2015.11.04

Emenusiobi, M.R., 2013, 'Africa: A continent of love for life and children', Evangelsuslife Africa, viewed 20 June 2018, from http://maryrosanna4life.blogspot.com/.
Falaye, T.A., 2016, 'Polygamy and Christianity in Africa', Global Journal of Arts Humanities and Social Sciences 4(10), 18-28.

Gitari, D., 1984, 'The church and polygamy', Transformation: An International Journal of Holistic Mission Studies 1(1), 3-10.

Handan, A.I., 2003, 'The Nigerian Baptist convention use of the bible in moral decision making about polygamy', MA thesis, Western Theological Seminary, Holland, MI.

Hastings, A., 1973, Christian marriage in Africa, SPCK, London.

Hillman, E., 1975, Polygamy reconsidered-African plural marriage and the Christian churches, TransAfrica Publishers, Orbis, Maryknoll, New York, NY.

Hillman, E., 1982, 'The polygamy debate: A progress report', Missiology: An Internationa Review 10(2), 161-169. https://doi.org/10.1177/009182968201000203

Igbelina-Igbokwe, N., 2013, 'Contextualizing gender based violence within patriarchy in Nigeria', Pambzuka News: Voices for Freedom and Justice, 12 pages, viewed 28 January 2018, from https://tinyurl.com/ycmmoy2g.

Jerome, O.M., 2016, 'Detachment as a prerequisite for a happy family: A study of Genesis 2:24', Mediterranean Journal of social Sciences 7(4), 526-532. https://doi. org/10.5901/mjss.2016.v7n4p526

King, C.I., 2016, 'The Anglican Communion's un-Christian stance on marriage', The Washington Post, 22 January 2016, viewed 15 July 2019, from https://www. washingtonpost.com/opinions/the-anglican-communions-un-christian-stanceon-marriage/2016/01/22/94cee988-c078-11e5-83d4-42e3bceea902_story. $\mathrm{html}$ ?noredirect=on\&utm term $=.704 \mathrm{~b} 084 \mathrm{cf} 10 \mathrm{c}$.

Koehler, L. \& Baumgartner, W., 2000, The Hebrew and Aramaic Lexicon of the Old Testament, Brill, Leiden.

Magnuson, K.T., 2000, 'Marriage, procreation and infertility: Reflections on Genesis', The Southern Baptist Journal of Theology 4(1), 26-43.

'Marriage and the Family in Africa', 1988, unlabeled, viewed 10 June 2018, from http://www.cormacburke.or.ke/node/288.

Mbiti, J.S., 1969, African religions and philosophy, Heineman, London.

Monroe, K. \& Monroe, P., 2005, 'The Bible and pain of infertility', Journal of Biblical Counseling 23(1), 50-58.

Moss, C.R. \& Baden, J.S., 2015, Reconceiving infertility: Biblical perspectives on procreation and childlessness, Princeton University Press, Princeton, NJ.

Murray, J., 1957, Principles of conduct: Aspects of biblical ethics, Eerdmans, Grand Rapids, Ml.

Muthengi, J.K., 1995, 'Polygamy and the church in Africa: Biblical, historical, and practical perspectives', Africa Journal of Evangelical Theology 14(2), 55-78.

Mwambene, L.M., 2017, 'What is the future of polygyny (polygamy) in Africa?', PER/ PELJ 20(1), 1-33. https://doi.org/10.17159/1727-3781/2017/v20i0a1357

Ntoimo, F.C., 2012, 'Prevalence, determinants and consequences of spinsterhood in Lagos, Nigeria', PhD thesis, University of Ibadan, Nigeria.

Ojua, T.A., Lukpata, F.E. \& Atama, C., 2014, 'Exploring the neglect of African family value systems and its effects on sustainable development', American Journal of Human Ecology 3(3), 43-50. https://doi.org/10.11634/216796221403585

Okonofua, F.E., Harris, D., Odebiyi, A., Kane, T. \& Snow, R.C., 1997, 'The social meaning of infertility in Southwest Nigeria', Health Transition Review 7(1), 205-220.

Okorie, A.M., 1995, 'African widowhood practices: The Igbo mourning experience', Africa Journal of Evangelical Theology 14(2), 79-84.

Olasore, R.E., 2016, 'The extent of polygamy in Africa: Any role for the information professionals in curbing further spread?', Information and Knowledge Management 6(6), 1-14.

Omeike, H.U., 2017, 'A theological retrieval of communal parenting as a mora response to baby stealing and childlessness in Nigeria', ThM thesis, Saint John's University, Collegeville, MN.

Onah, R.C., 1996, Religion and society, Fulladu, Nsuka.

Pearce, T.O., 1999, 'She will not be listened to in public: Perceptions among the Yoruba of infertility and childlessness in women', Reproductive Health Matters 7(13), 69-79. https://doi.org/10.1016/S0968-8080(99)90114-3

Peel, D.N., 1987, 'Procreation', in R.K. Harrison (ed.), Encyclopedia of Biblical and Christian ethics, pp. 320-341, Thomas Nelson Publishers, Nashville, TN.

Ryan, M.A., 2005, 'Faith and infertility', in Christian Reflection, pp. 65-74, The centre for Christian Ethics, viewed 22 March 2020, from https://www.baylor.edu/ifl/ christianreflection/CloningarticleRya.pdf.

Stent, W.R., 2019, 'Polygamy and the Missionary Church', Academia, viewed 28 June 2019, from https://www.academia.edu/32722771/Polygamy_1_and_ the Missionary_Church.

Uchem, R.N., 2016, 'Polygamy as a solution to the problem of childlessness: A case study of cultural oppression of women', Research Gate. https://doi.org/10.13140/ RG.2.1.2803.8646

Webster, J.B., 1964, The African Churches among the Yoruba: 1888-1922, Clarendon Press, Oxford.

Wenham, G.J., 1987, Genesis 1-15: Word Biblical commentary, Word Books, Waco, TX. 